\title{
Kekerasan dan Ketakutan pada Kekerasan
}

\author{
Suparman Marzuki
}

The social violence phenomenon can not be explained and related to the structural domains only, but it is also involved and influenced by social, political, law and that of politician and leaders behavior. In Western societies is not so urgent to relate the politician and the leaders behavior, but for Indonesian nation that of behavior is involved because social relation between leaders and their community sometimes supported: and directed by social trust, instead that of spiritual. This relation has psychological. dimension which can be stabilization and anarchy factors. In this respect, the role of law, law enforcement, the institution of law should be first priority to control, minimize violence, and fear of violence.

Kata kunci: kekerasan, struktur, anarkis, ketakutan, dan pemimpin.

D i' saat transisi politik menuju demokrasi sedang berlangsung, fenomena kekerasan dalam pelbagai bentuk di beberapa tempat di tanah air, seperti pembunuhan, perampokan, penembakan gelap, intimidasi, pengeboman, tawur massal, penyerangan, pengusiran, dan macammacam bentuk kekerasan masih saja terjadi' . Keadaan ini sungguh memprihatinkan karena semakin menambah beban masyarakat dan bangsa ini. Pemberitaannya tidak hanya monopoli (koran kuning), tetapi juga oleh (koran elite) bangsa kita. Barangkali orang másih akan memperdebatkan tentang apakah kekerasan di Indonesia benar-benar tidak terkendali, apakah bukannya merupakan hasil pemberitaan media massa yang makin intensif? Perdebatan metodologis seperti itu bolehlah kita kesampingkan, oleh karena yang tampak sekarang adalah menguatnya perasaan takut kepada kekerasan (fear of violence)

1 Jamil membagi kekerasan ke dalam beberapa bentuk. Pertama, Kekerasan langsung berupa: pembunuhan, tindakan brutal, pembatasan atau tekanan fisik, penculikan, penyandaraan, pemenjaraan; dan buruh kerja paksa. Kedua, kekerasan tidak langsung beruapa: pelanggaran tidak langsung terhadap hak untuk bertahan hidup manusia, kekerasan karena pembiaran, langkanya perlindungañ dari kekerasan sosial (kelaparan, wabah penyakit, kemiskinan), langkanya perlindungantdari kecelakaan, langkanya perlindungan dari 
Spekulasi pun bermunculan; sebagian melihatnya wajar (logis) terjadi di era transisi sebagai reaksi atas terbukanya katub-katub penekan yang terpasang puluhan tahun, sehingga ketika kebebasan diberikan, reaksi masyarakat laksana air bah yang melandalandan tidak terbendung meluapkan protes atau ketidaksukaannya terhadap apa saja dengan cara-cara (salah satunya) kekerasan. Sebaliknya, ada yang melihatnya sebagai rekayasa (by design) dari kekuatan-kekuatan struktur lama yang tidak setuju dengan perubahan dan tidak rela dengan pergantian, dan seterusnya. Tetapi apapun analisis itu, ada keragaman pendapat bahwa peristiwa kekerasan yang timbul di dalam perubahanperubahan masyarakat seringkali tidak mudah diidentifikasi; yang pasti kekerasan itu memiliki akar masalah yang bersifat laten atau tersembunyi di tengah masyarakat terutama karena faktor konflik atau persaingan kepentingan di sektor politik (kekuasaan) dan ekonomi, selain karena faktor ketidakmampuan negara menegakkan keadilan sosial (Camara; 2000).

Paralel dengan fenomena kekerasan itu, muncul pula gejala meningginya ketakutan pada kekerasan (fear of violence) di kalangan masyarakat, yang telah melahirkan kekerasan-kekerasan baru. Apa dan bagaimana kekerasan serta ketakutan pada kekerasan it?, merupakan fokus analisis tulisan ini.

\section{Struktur sebagai kausa kekerasan}

Ada banyak analisis yang menjelaskan kekerasan². Smelser (1971) misalnya mengemukakan, ada empat hal yang menjadi dasar timbulnya tindakan kekerasan: Pertama, tindakan yang berorientasi nilai yang dimobilisasi atas nama kepercayaan umum dalam rangka menginginkan atau menghendaki perumusan kembali nilai-nilai. Kedua, tindakan yang berorientasi pada norma umum atau kepercayaan umum yang menginginkan atau menghendaki perumusan kembali nilai-nilai. Ketiga; tindakan yang muncul karena ledakan kebencian, dan keempat, tindakan yang muncul dari kegalauan atau kepanikan dan merupakan bentuk perilaku yang dilandasi oleh suatu redefinisi umum terhadap fasilitas. yang tersedia.

Pada umumnya, kekerasan terjadi kerena diawali oleh rasa kebencian terhadap struktur atau sistem yang seharusnya bertanggung jawab atas suatu keadaan yang tidak diinginkan. Di balik kekerasan itu, sebenarnya secara implisit termuat tuntutan agar nilai-nilai atau norma-norma yang berlaku saat ini direvisi atau dirumuskan ulang. Nilai-nilai atau norma-

kekerasan alam (bencana alam, badai, gunung meletus, gempa bumi, banjir). kekerasan dengan mediasi (modifikasi rentan berbahaya terhadap lingkungan alam dan sosial. Ketiga, kekerasan Represif berupa: perampasan hak-hak fundamental (hak sosial, serikat kerja industri atau perdagangan, kesetaraan sosial dan jender, partisipasi dalam kehidupan sosial dan ekonomi, perlindungan atas hak milik pribadi dan hak milik sosial, hak-hak sipil warga negara, dan hak-hak politik. Keempat, kekerasan alienatif berupa: perampasan hak-hak yang lebih tinggi, pengasingan habitat dan kondisi hidup, pengasingan pergaulan sosial, dan pemusnahan. Lebih lanjut baca; Jamil Salmi, Violence and Democratic Society, Pilar, 2005

2 Buku-Buku menarik yang mengulas mengenai kekerasan antara lain: Violence and Democratic soviety, Hologanisme dan masyarakat demokrasi, Pilar, 2005; Thomas Santoso, Teori-Teori Kekerasan, GI, 2002, I. Marsana Windhu (ed) Kekuasaan dan kekerasan Menurut John Galtung (Terj), Kanisius, 1992; Jack D. Douglas and Frances Chaput Waksler, .Violence", dalam The Sociology of Devieance, An Introduction, Boston: Liitle Brown and Company, 1982 
norma itu sangat berkait erat dengan normanorma politik, ekonomi, dan hukum yang dituntut lebih terbuka, demokratis, adil, dan mengandung kepastian. Dalam kata lain, Smelser ingin mengatakan bahwa di balik berbagai tindakan kekerasan itu termuat tuntutan perubahan yang didorong dan dikondisikan oleh problem-problem kepincangan dan ketegangan struktural, pertumbuhan, dan penyebaran kepercayaan umum serta adanya faktor pencetus.

Kesadaran sebagian besar orang pada realitas pengecualian-pengecualian (peminggiran) ekonomi dan politik menjadi dorongan struktural yang kemudian menimbulkan ketegangan struktural:Dalam kata lain, menurut Galtung, ketidakseimbangan relasi sosial semacam itu terjadi karena adanya perbedaan dalam segi "ada" (being), "memiliki" (having), dan "kedudukan" dalam suatu struktur (Windu, 1992). Lama-kelamaàn dorongan dan ketegangan struktural itu tumbuh menyebar menjadi kepercayaan umum. Siapa saja yang terkecualikan (terpinggirkan) dari berbagai akses sosial, ekonomi, dan politik akan merasakan bèrada dan menjadi bagian dari kepercayaan umum itu. Akibatnya, bila terjadi sedikit saja isu atau nyata-nyata ada tindakan kekerasan dari manapun datangnya dan siapapun yang memulainya akan menjadi faktor pencetus lahimya kekerasan. Dalam konteks ini, sulit menyatakan begitu saja bahwa suatu peristiwa kekerasan bersifat terstruktur. Oleh karena itu, tidak mudah pula untuk meminta atau menuntut sebuah tanggung jawab pada struktur tertentu tanpa melihat kompleksitas latar belakang kekerasan itu.

Fenomena di atas itulah yang menumbuhkan situasi ketidakamanan sosial (social unrest) yang pada gilirannya menimbulkan mekanisme psikis tertentu seperti pengkambinghitaman terhadap pihak-pihak yang dianggap sebagai pihak luar (outgroup). Pihak luaritu pun bermacammacam tergantung pada identifikasi ${ }^{\top}$ dan bayangan mereka masing-maśsing, meskipun umumnya dikenakan pada kelompok yang dianggap berlebih secara ekonomi (the haves). Mekanisme psikis ini biasanya muncul setelah seseorang atau sekelompok orang mengalami fase frustasi, yang akan terlampiaskan melalui tindakan agresif (kekerasan). Oleh Gurr (1970), agresi karena frustasi ini disebut sebagai hubungan yang bersifat basic motivational link atau tindakan agresif yang secara dominan dimotivasi oleh pengalaman frustrasi. Dalam kata lain, frekuensi tingkah laku kekerasan itu berbanding lurus dengan besarnya frustasi yang dirasakan seseorang atau sekelompok orang. Bila ada dorongan intensif yang merespon atau memotivasi frustrasi itu, maka seseorang akan kehilangan kontrol atau kesadaran rasional.

Johan Galtung (2002) yang mengidentifikași tipologi dasar dan latar belakang kekerasan menggambarkan sebagaimana tabel 1.

Menurut Galtung, keempat golongan kebutuhan dasar dalam kolóm di atás terpilah dalam dua bentuk kekerasan yaitu kekerasan langsung dan kekerasan struktural. Sedangkan dari keempàt kebutuhan dasar dalam kolom di atas, terdapat pula negasi-negasi yaitu 1 ) kebutuhan survival dengan kematian atau mortalitas sebagai negasinya; 2) kebutuhan kesejahteraan dengan penderitaan atau morbiditas sebagai negasinya; 3) kebutühan identitas atau makna dengan alienasi atau keterasingan sebagai negasinya; dan 4) kebutuhan pada kebebasan dengan represi sebagai negasinya.

Berdasarkan hasil persilangan kolom dan lajur bagan kekerasan di atas maka tampaklah delapan subtipe kekerasan A Akan tetapi, menurut Galtung, mengidentifikasi 
Topik: Budaya Kekerasan

Tabel 1

\begin{tabular}{|l|l|l|l|l|}
\hline $\begin{array}{l}\text { Akar dan Tipe } \\
\text { Kekerasan }\end{array}$ & $\begin{array}{l}\text { Kebutuhan } \\
\text { Survival }\end{array}$ & $\begin{array}{l}\text { Kebutuhan } \\
\text { Kesejahtera-an }\end{array}$ & $\begin{array}{l}\text { Kebutuhan } \\
\text { Identitas }\end{array}$ & $\begin{array}{l}\text { Kebutuhan } \\
\text { Kemerdeka-an }\end{array}$ \\
\hline $\begin{array}{l}\text { Kekerasan } \\
\text { langsung. }\end{array}$ & Pembunuhan. & $\begin{array}{l}\text { Pengepungan; } \\
\text { Derita sanksi. }\end{array}$ & $\begin{array}{l}\text { Desosialisasi; } \\
\text { Resosialisasi; } \\
\text { Warganegara } \\
\text { kelas dua. }\end{array}$ & $\begin{array}{l}\text { Represi; } \\
\text { Penahanan; } \\
\text { Pengusiran. }\end{array}$ \\
\hline $\begin{array}{l}\text { Kekerasan } \\
\text { struktural. }\end{array}$ & Eksploitasi A. & Eksploitasi B. & $\begin{array}{l}\text { Penetrasi; } \\
\text { Segmentasi. }\end{array}$ & $\begin{array}{l}\text { Marjinalisasi; } \\
\text { Fragmentasi. }\end{array}$ \\
\hline
\end{tabular}

kekerasan langsung akan lebih mudah dibanding mengidentifikasi kekerasan struktural karena persoalan struktural bersifat lebih kompleks dan sistematis. Selain itu, ada instrumen-instrumen lain yang dapat melegitimasi kekerasan langsung dan kekerasan struktural itu dan instrumen-instrumen itu disebut Galtung sebagai.kekerasan kultural. Contoh-contoh instrumen yang dimaksud Galtung sebagai kekerasan kultural itu ialah agama, ideologi, bahasa, seni, ilmu dan pengetahuan empiris, ilmu dan pengetahuan formal, dan kosmologi.

Kekerasan struktural yang dimaksud oleh Galtung itu adalah aspek-aspek budaya atau wilayah simbolis eksistensi manusia. Ciri-ciri yang disebutkan di atas adalah "aspek-aspek dari budaya", dan bukan keseluruhan budaya karena hanya menyangkut sistem simbolis manusia seperti bintang, salib, bulan sabit, bendera, lagu-lagu kebangsaan, parade militer, pakaian seragam, foto seorang pemimpin, suara pidato, poster-poster yang membakar, dan seterusnya. Dengan demikian, melalui pengertian ini kita dapat memilahkan dua hal yaitu tentang "kekerasan budaya" (culture violence) dan "budaya kekerasan" (violent cultures). Akan tetapi, menurut Galtung, seluruh kebudayaan hampir tidak mungkin diklasifikasikan keras. Oleh karena itu, kita memiliki alasan untuk memilih ungkapan berikut: "Aspek A darikebudayaan Cadalah suatu contoh kekerasan kultural" daripada stereotype ungkapan bahwa "budaya C itu ' keras" (Galtung, 2002)

Jadi, ada persoalan psikoetnik atau psikobudaya yang tidak bisa dipungkiri oleh Galtung sehingga suatu kekerasan tidak selalu dapat dituduh sebagai kebiadaban. Dalam bahasa Erich Fromm, kekerasan itu menjadi kajian psikoanalisis karena akar utamanya justru terletak pada manusia secara individual. Kekerasan tidak berakar dari sebuah insting layaknya pada hewan. Banyak bukti penelitian paleontologi, antropologi, dan sejarah yang membantah tesis kekerasan instingtif itu dengan kesimpulan bahwa: 1) kelompok manusia memiliki tingkat destruktif yang berbeda secara fundamental satu sama lain sehingga fakta-faktanya tidak selalu dapat dijelaskan dengan asumsi seolah-olah kedestruktifan dan kekejaman manusia itu adalah pembawaan;2)beragamtingkatkedestruktifan manusia itu bisa dikorelasikan dengan faktor-faktor psikis yang lain dan perbedaan dalam masing-masing struktur sosialnya; dan 3) derajat kedestruktifan manusia itu meningkat seiring meningkatnya perkembangan peradaban, dan bukan sebaliknya (Fromm, 2001).

Jadi, manusia memiliki energi dasar untuk tumbuh dan berkembang. Apabila energi itu terhalang secara paksa, maka 
energi itu akan beralih menjadi energi yang bersifat merusak sebab tidak tersalur secara alami. Kondisi-kondisi individual dan sosial yang menghalangi pertumbuhan dan perkembangan energi manusia itulah yang akan menghasilkan sifat destruktif atau sifat merusak sehingga termanifestasi menjadi kekerasan.

Hasil penelitian Pusat Penelitian Pengembangan Kawasan Universitas Gadjah Mada yang bekerja sama dengan Departemen Agama Republik Indonesia pada tahun 1997 (Loekman Soetrisno, dkk., 1997), menyebutkan bahwa berbagai kasus kekerasan di Indonesia, sangat sarat dengan warna politik karena menyangkut tiga masalah yaitu, 1) negara; 2) struktur sosial; dan 3) personal (komunitas). Secara detil, karakteristik tindak kekerasan dalam masyarakat yang ditemukan oleh tim peneliti Pusat Penelitian Pembangunan Pedesaan dan Kawasan Universitas Gadjah Mada itu terlihat pada bagan di bawah ini: masyarakat sangat rentan menjadi konflik; 2) ketimpangan antarpelaku ekonomi yâng ditandai oleh persaingan yang tidak sehat antara pelaku ekonomi lemah dan ekonomi kuat; 3) kecemasan masyarakat akibat kehilangan kendali atas nasib mereka sendiri dan juga karena ketidakmampuan mereka berpartisipasi dalam proses pembuatan keputusan publik yang mempengaruhi masa depan rakyat; 4) ketidakpercayaan masyarakat pada birokrasi pemerintah yang ditandai oleh berbagai pelayanan publik yang buruk dan korup; 5) proses integrasi masyarakat yang belum tuntas kerena dilakukan secera represif oleh negara; 6) sosialisasi ajaran agama yang mendorong umat melakukan tindakan yang militan; 7) karakteristik konflik dan tindak kekerasan yang ternyata didominasi oleh pelakú bisnis besar karena perilaku eksploitatifnya, dan oleh aparat negara karena perilaku korupsi atau kepentingan kekuasaannya; dan 8)

Tabel 2

\begin{tabular}{|c|c|c|c|c|}
\hline$\overline{\text { ARAS }}$ & PELAKU & DIMENSI & $\begin{array}{l}\text { MEDIUM/ } \\
\text { SARANA }\end{array}$ & RUANG LINGKUP \\
\hline Negara & $\begin{array}{l}\text { Aparat } \\
\text { negara. }\end{array}$ & $\begin{array}{l}\text { Fisik dan } \\
\text { nonfisik (teror } \\
\text { mental). }\end{array}$ & $\begin{array}{l}\text { Senjata dan } \\
\text { organisasi } \\
\text { tentara/polisi; } \\
\text { Kebijakan Publik. }\end{array}$ & $\begin{array}{c}\text { Komprehensif. } \\
\text {. }\end{array}$ \\
\hline $\begin{array}{l}\text { Struktur } \\
\text { Sosial }\end{array}$ & $\begin{array}{l}\text { Aparat } \\
\text { negara; } \\
\text { Pengendali } \\
\text { kapital/ } \\
\text { modal. }\end{array}$ & $\begin{array}{l}\text { Nonfisik } \\
\text { (Politik, } \\
\text { Ekonomi, } \\
\text { Sosial, dan } \\
\text { Budaya). } \\
\end{array}$ & $\begin{array}{l}\text { Kebijakan Publik; } \\
\text { Proses dan sarana } \\
\text { produksi/ } \\
\text { akumulasi kapital. }\end{array}$ & $\begin{array}{c}\text { Komprehensif., } \\
. \\
.\end{array}$ \\
\hline $\begin{array}{l}\text { Personal/ } \\
\text { Komunitas }\end{array}$ & $\begin{array}{l}\text { Individu; } \\
\text { Kelompok. }\end{array}$ & Fisik. & $\begin{array}{l}\text { Kelompok anomie; } \\
\text { Tindakan individual. }\end{array}$ & Terbatas. \\
\hline
\end{tabular}

Dari ragaan di atas tersimpul beberapa masalah yang menjadi akar atau faktor dasar munculnya kekerasan di tengah masyarakat yaitu, 1) dampak pembangunan yang terlalu menekankan akumulasi kapital (modal) sehingga konfigurasi pemilahan sosial dampak negatif dakwah agama pada sukusuku pedalaman.

Dengan bahasa yang berbeda dan substansi yang sama, Dom Helder Cânara menengarai sebab kekerasan bersumber 
pada ketidakadilan. Dan kekerasan menurutnya merupakan gejala yang menimpa perorangan, kelompok, atau negara karena ketidakadilan sosial dan ketimpangan ekonomi. Kekerasan tahap ini diyakini Camara akan mengakibatkan kondisi "sub-human" atau kondisi di bawah standar hidup layak sebagai manusia normal. Kondisi "sub-human" ini akan mengakibatkan pemberontakan di kalangan masyarakat sipil sebab dalam kondisi ini manusia mengalami tekanan psikologis, ketarasingan (alienasi), dehumanisasi martabat, atau tekanan struktural. Selanjutnya, kekerasan dapat muncul dalam bentuk represi penguasa (aparatur negara) terhadap rakyat. Kekerasan ini terjadi karena adanya perlawanan oleh kelompok pelaku kekerasan karena terjadinya ketidakadilan. Dengan demikian, terjadilah satu bentuk kekerasan yang disebut Camara dengan Spiral Kekerasan.

Dengan teori ini Camara menyebutbahwa kekerasan dapat dirunut dari tiga akar pelaku yaitu personal, institusional, dan struktural. Tiga akar pelaku kekerasan itu dapat dijelaskan lagi berdasarkan sifatnya atau faktafakta yang terjadi dalam masyarakat yaitu ketidakadilan, kekerasan pemberontakan sipil, dan represi negara. Ketiga sifat penyebab kekerasan ini sangat terkait satu sama lain dan dapat pula muncul secara beruntun atau susul-menyusul. Dengan demikian, menurut Camara,kekerasan pasti muncul secara spiral oleh kenyataan bahwa di tengah masyarakat telah terjadi: 1) ketidakadilan atau ketimpangan; 2) fakta pada poin ke-1 itu akan mengakibatkan pemberontakan sipil; dan 3) fakta pada poin ke-2 itu otomatis akan melahirkan represinegara (Camara, 2002:3139).

Kekerasan di Indonesia memang bersentuhan dengan problem-problem politik. Schulte-Nordholt (2002: 37), misalnya menyatakan bahwa kekerasan politik di Indonesia bersifat sangat geneologis karena pola-pola tertentu dari kekerasan itu sangat mirip dengan pola-pola kekerasan sebelumnya. Bahkan, aktor-aktor pelaku kekerasan itu seringkali mendasarkan pendekatan mereka pada pengalaman-pengalaman dan contoh-contoh yang diperoleh dari warisan generasi sebelumnya. Henk (hal:39-40 dan 55-56) menyebut ada dua gelombang kekerasan yang telah terjadi di Indonesia, yaitu: Pertama, abad ke-17 ketika VOC ingin menegakkan monopoli perdagangannya dengan menaklukkan tempat-tempat strategis seperti Makassar, Malaka, dan Banten. Kedua, kekerasan yang terjadi antara tahun 1871 hingga 1910 ketika penduduk Indonesia mengalami ekspansi imperialis kekuasan kolonial. Penguasa kolonial itu pun menggembar-gemborkan sebuah negara kolonial baru dengan pasokan artilerinya yang tidak memadai untuk mencapai tujuan itu. Oleh karena itu, kekerasan-kekerasan atau perang-perang lokal tidak dapat dihindari. Selama periode ini, telah terjadi 32 episode perang kolonial di seluruh kepulauan Nusantara.

Turunan dari kekerasan historis itu kian menemukan formatnya yang tetap pasca kemerdekaan Indonesia melalui berbagai peristiwa seperti kekerasan yang terjadi dalam kasus G-30-S/PKI maupun saat pembantaian terhadap orang-orang Partai Komunis Indonesia (PKI) sepanjang tahun 1965-1966 yang dilakukan oleh kelompok sipil maupun militer. Selanjutnya, sepanjang Orde Baru, berbagai kekerasan oleh sipil maupun militer tidak dapat lagi dipisahkan dari wilayah kekuasaan politik maupun kekuasaan modal (kapital).

Intervensi militer Amerika Serikat ke sejumah negara di pelbagai belahan dunia merupakan tindakan kekerasan yang dipicu 
oleh kepentingan politik dan ekonomi negara adi daya itu. Jamil (2005) misalnya mencatat bahwa peran Amerika Serikat dalam menebar kekerasan karena alasan politik dan ekonomi telah terjadi berulang-ulang. Antara tahun 1789 sampai 1895, tentara Amerika Serikat melakukan intervensi ike negara lain sebanyak 103 kali, kemudian antara 1896 sampai 1945 sebanyak 57 kali, dan antara 1945 sampai 1991 sebanyak 218 kali (termasuk ke Grenada, Panama dan Irak). Intervensi yang p̀aling mencolok tentara Amerika Serikat dan atau CIA dalam kurun waktu terakhir adalah: (a) usaha untuk menggulingkan pemerintahan yang sah karena kebijakan ekonominya yang bertentangan dengan kepentingan negaranegara kapitalis, misalnya di Iran (1953), Guetemala (1954), Kuba (1961 dan 1971), Brasil (1964), Yunani (1967), Chili ( 1973), Angola.(1974-1975), Jamaika (1975), Grenada (1983), Nikaragụa (sejak 1984); dan (b) intervensi untuk mendukung pemerintahan represif yang mendukung stabilitas serta protes, misalnya di Honduras (1954), Libanon (1958), Thailand (1959), Laos (1959-1969), Ethiopia (1960), Korea Selatan (1960), Guyana (1963), Vietnam (1964), Republik Dominika (1962 dan 1965, Kambodia (1968-1970, Guatemala dan EI Salvador (sejak 1981).

\section{Faktor sosial kekerasan}

Di samping kausa struktur, kekerasan juga tidak dapat dilepaskan dari realitas masyarakat yang penuh dengan patologi sosial. Ada banyak anomali-anomali sosia! yang terjadi di depan mata dan sudah pula menjadi rahasia umum bagi masyarakat. Sebagai contoh, ada kemiskinan karena dampak pembangunan yang tidak adil, hilangnya pekerjaan akibat PHK sewenangwenang, ada gelandangan dan pengemis yang terorganisasi atau dieksploitasi, ada pengangguran kaum terdidik, korupsi, kolusi, nepotisme (KKN), atau kemaksiatan yang melibatkan para pejabat publik, dan sebagainya. Semua yang tampák ini.kian tipis pula dimensinya dengan kehidupan spiritual yang sering pula dipertontonkan oleh kaum berpunya (the haves) di muka umūum.

Dalam aspek ekonomi, terjadi perburuan harta dengan cara menghalalkan segala cara. Pada saat yang sama, gaya hidup materialistis dan hedonis digelar di berbagai momen dan media. Bahkan, dipertunjukkan tanpa menimbang sisi moral dan etika yang dianut sebagian masyarakat. Pada bagian lain, di sektor-sektor perburuhan terjadi pula pergolakan yang keras antara pemilik modal dan kaum buruh hingga terjadi berbagai gelombang demonstrasi yang memicu kekerasan terhadap kaum buruh dan sebaliknya.

Keserakahan manusia sebagai kata lain perburuan harta benda yang menghalalkan segala cara, tidak muncul tiba-tiba, tapi melalui proses interaksi manusia dengan kehidupan kapitalis yang memang dibangun dengan etos semacam ịtu. Buku The Wealth of Nation (1876) merupakan proklamasi yang paling berhasil yang menyatakan bahwa keserakahan individual tidak bertentangan dengan kepentingan umum. Keserakahan akan harta benda bukan merupakan sesuatu,yang aib, melainkan berguna bagi masyarakat secara keseluruhan. Keserakahan membuat manusia bekerja keras untuk mencari keuntungan. Keserakahan ini kata Smith tidak akan membuat orang menindas orang lain karena keserakahan satu orang akan diimbangi oleh keserakahan orang lainnya, maka terjadi kompetisi bebas yang sehat. Dengan adanya kompetisi yang sehát ini, maka seorang buruh yang ditindas ôleh seorang majikan, akan dengan mudah 
pindah ke majikan lainnya yang kurang menindas. Akibatnya, karena kekurangan buruh, maka majikan yang pertama akan mengurangi' tingkat eksploitasinya.

Smith" mungkin tidak membayangkan bawa keserakahan yang ia yakini tidak akan menimbulkan penindasan. atau kekerasan berbalik seratus delapan puluh derajat.Keserakahan telah menjadi semacam (kangker akut) yang terusmenerus 'menggerogoti tubuh manusia hingga manusia itu mati secara perlahanlahan atau dalam konteks ini menjadi beringas, kejam dan sadis yang melumpuhkan seluruh potensi kontrol internal dan eksternalnya.

Secara sosiologis, keserakahan dan kekerasan seolah mendapat tempat hidupnya yang subur di perkotaan karena pertumbuhan kota ditandäi 'oleh heterogenitas dan anomitas, perubahan-perubahan sosial, persaingan, orientasi materialistis dan bangkitnya kecenderungan egoisme dan individualisme. Implikasi dari pertumbuhan sistem kapitalis itu di sektor kota memang tidak selalu secara langsung menimbulkan prilaku distruktif (kekerasan), tapi ia telah menjadi faktor amat penting yang mengkondisikan tumbuhnya individualisme, keserakahan, ketegangan-ketegangan dalam hubungan sosial pada semua tingkat. Itu semua pada akhirnya akan melahirkan kekerasan bila sedikit saja dipicu oleh faktor pencetus.

Hepotesis pengaruh sistem kapitalisme (keserakahan) atas kemunculan kekerasan kian tak terbantah, setelah melihat gejalayang sekarang terjadi di Eropa Timur dan bekas Uni Soviet. Reformasi ke arah sistem ekonomi kapitalis di sana temyata telah membuat gelombang tindak kejahatan sebagai bagian realitas kehidupan seharihari dalam masyarakat. Begitu pula yang sekarang melanda China (Kompas, 7-1-94).
Dorongan yang melekat dalam suatu sistem kapitalis untuk mencapai maksimum akumulasi modal, maksimum produksi dan konsumsi serta berbagai dimensi kekuatan mekanisme pasar lainnya (termasuk dimensi kekuasaan politik) di dalamnya telah mémaksa diri setiap manusia menjadi homo economicus yang semata-mata digerakkan oleh rasionalitas instrumental pencarian laba di satu pihak dan membuat sebagian masyarakat tercecer tak mampu menempatkan diri di dalamnya.

Dalam pengamatan Ricard Quenney (1977) sistem kapitalis tampaknya memang memproduksi dan memelihara sumber-sumber kejahatan karena ia fungsional atas sistem itu. la mencatat tiga jenis kejahatan, satu diantaranya yang penting dicatat adalah the crimes of acomodation; kejahatan yang muncul sebagai pilihan rasional pelaku untuk menyesuaikan diri dengan pola pencapaian maksimum konsumsi yang didorong kuat oleh sistem kapitalis, ataupun hanya sekedar upaya untuk bertahan hidup dalam sistem di mana institusi-institusi perlindungan sosial kolektif telah diperiemah demi efisiensi pertumbuhan kapitalis. Letak fungsionalnya justru karena ia memberikan kontribusi bagi kelangsungan sistem kapitalis, yakni memelihara daya beli atau kemampuan konsumsi kelompok kriminal, yang notabene adalah kelompok sosial yang tak memiliki modal produksi. Yang mengherankan justru jenis kejahatan ini yang menjadi orientasi penanggulangan kejahatan pada sebagian besar negara dunia ketiga, termasuk Indonesia, padahal kejahatan ini tidak lain sekedar implikasi dari jenis kejahatan lain yang oleh Queney disebut the crimes of economic domination serta the crime of govemmen.

Di dunia profesional juga mengalami degradasi yang ditandai oleh hilangnya etika 
profesi. Bagi seorang dokter, misalnya, pasien tidak lagi dianggap sebagai pihak yang memiliki hak atas pelayanan kesehatan, melainkan semata sebagai komoditi atau konsumen yang semata ingin membeli kesehatan. Hubungan pasien dan dokter pun berubah menjadi hubungan ekonomi yang cenderung menanggalkan sisi kemanusiaan.

Institusi sekolah yang mestinya menjadi tempat memupuk kedalaman hati nurani dan ketinggian akhlak nyaris diformat laksana mesin industri yang bergerak mekanis; menerima masukan sejumlah orang untuk diolah secara mekanis pula. Semua mereka dikerangka dengan target dan tujuan yang seolah-olah pasti meski sebenarnya penuh ketidakpastian. Fungsi pendidikan telah kehilangan prinsipnya yang paling dasar, yaitu pendidikan itu sendiri karena lulusan yang dihasilkan dunia pendidikan-mengutif C.Wright Mills—-telah mengalami reduksi nalar menjadi (rasionality without reason). Mereka cenderung menjadi (cheerful robot) yang mempunyai rasio tanpa akal budi sehingga kehilangan daya kreatif. Tidak salah jika peserta didik dan lulusan sekolah jaman ini mengalami keterasingan diri dari realitas diri, realitas sekolah dan realitas masyarakat. Mereka tidak tahu dan tidak bisa lagi mengukur kemampuan dirinya, sekaligus kehilangan kepercayaan atas segala ukuran semacam itu karena telah kehilangan relevansi. Sekolah telah menjadi institusi yang membuat anak didik berekstasi dalam bentuk lain.

Lingkungan alam perkotaan terasa semakin tidak nyaman untuk dihuni. Eksploitasi atas lingkungan perkotaan yang makin terbatas untukmembangun segala kebutuhan simbul-simbul modernitas: mall, bioskop, pabrik-pabrik, dan lain sebagainya secara langsung menimbulkan pelbagai dampak sosial psikologis bagi penghuninya.

Pada aspek lain di bidang penegakan hukum, masyarakat dipertontonkan dengan fenomena hipokrisi. Lembaga.hukum yang harusnya menjadi tempatdan harapan pencan keadilan, justru menghinanya: Lembaga yang mestinya menjaga martabat dan harga diri hukum, justru menghancurkannya. Personal profesional hukum yang seharusnya berada di depan mempertaruhkan segalanya demi hukum, justru merusaknya. Lembaga. dan personal yang semestinya menjadi lokomotif reformasi. segala bidang, justru menjadi gerbong yang keluar rel.

Prilaku demikian itu membuat penegakan hukum tidak mewujudkan pencerahan, rasa aman dan melindungi, tapi justru sangat menekan, membuat sumpek, sekaligus tak memberi harapan. Kekuasaan kehakiman menjadi kekuasaan alienatif yang kuat mencerminkan rekayasa struktur yang menghasilkan kepatuhan karena tekanan. Kekuasaan moral yang dibangun di atas dasar konsensus normatif dan dipatuhi secara moral-pun dengan sendirinya sirna. Celakanya kekuasaan alienatif tadi menemukan jalinan logisnya dengan kekuasaan kalkulatif yang bersifat pragmatis: menghitung apa yang akan diberikan oleh sang penguasa berdasarkan berapa banyak yang akan diterima. Kepatuhan pun bersifät pragmatis, tergantung pada pertukaran antara pemberian (hadiah) dengan penerimaan balik.

Praktek penegakan hukum hingga sekarang berada dalam logika "take" atau logika jual beli. Dalam logika ini, pengadilan tidak lebih seperti panggung sandiwara yang memiliki sutradara, skenario, kru dan aktornya sendiri yang mementaskan lakon apa saja: Dalam panggung itu peristiwa 
hukum adalah naskah ceritera yang mempertemukan para pihak dalam logika jual beli.

Hakim yang diharapkan mandiri dan tidak terpengaruh oleh kekuatan apapun dihadapkan pada realitas eksternal dan internainya sendiri yang membuat hakimhakim kita tak kuasa menjadi simbul moralitas, simbol progresifitas hukum (istilah Satjipto). Hakim-hakim kitameminjam pandangan filsuf Karl Jaspersterperangkap dalam situasi perbatasan (Grenzsituation-en), yaitu keadaan yang dihayati oleh si manusia yang tahu tentang apa yang seharusnya ia lakukan, tetapi realitas konkret membuat dirinya tak bisa melakukan apa-apa.

\section{Ketakutan Pada Kekerasan}

Fenomena lain yang merebak mengikuti kekerasan adalah meluasnya tingkat ketakutan pada kekerasan itu sendiri (fear of violence). Ketakutan masyarakat itu bisa saja merupakan reaksi emosional yang wajar, yang biasanya ditandai oleh perasaan terancam bahaya. Ketakutan tersebut bisa berupa ketakutan aktual dan ketakutan antisipatif. Ketakutan aktual adalah ketaku-tan yang timbul ketika ancaman kekerasan memang nyata-nyata dirasakan menganicam. Hal ini bisa terjadi misalnya terhadap seseorang atau masyarakat yang tinggal di lingkungan yang tingkat kejahatannya tinggi atau pernah menjadi korban kekerasan. Sementara ketakutan antisipatif'adalah ketakutan yang timbul karena bayangan atau perasaan akan menjadi korban kekerasan.

Kedua jenis ketakutan itu pada dasarnya berhubungan secara timbal balik. Ketakutan aktual potensial menimbulkan ketakutan antisipatif dan sebaliknya ketakutan antisipatif dapat menimbulkan ketakutan aktual. Pengaruh timbal balik ini bisa disebabkan oleh lima hal, yaitu: (a) karaktrestik sosial dan ekonomi (usia, jenis kelamin, pendapatan, tingkat pendidikan, lokasi geografis, tinggi rendahnya penghayatan keagamaan dan sebagainya.

Pada masyarakat yang status sosial ekonomi, pendidikan dan penghayatan agamanya rendah, ada kecenderungan memiliki reaksi emosional yang tinggi dibandingkan rasionya; (b) informasi tentang kekerasan (jumlah dan sifat informasi, pengalaman langsung, komunikasi interpersonal secara langsung atau tidak langsung; (c) faktor-faktor antara (sikap dan kepentingan yang mempengaruhi perșepsi selektif atas informasi yang tersedia); (d) gambaran tentang kekerasan (luas kekerasan di lingkungannya, sifat dan seriusitas kekerasan, akibat fisik dan psikis, dII), dan (e) penilaian atas risiko (pandangan bahwa seseorang atau kelompok masyarakat tertentu akan menjadi target potensial kekerasan, akibat-akibat yang timbul, dan seterusnya).

Respon dari rangkaian ketakutan itu dapat bermacam-macam antara lain (a) perilaku menghindar dengan tindakan mengurangi risiko, misalnya pindah tempat tinggal atau menjauhi situasi-situasi yang menakutkan; (b) perilaku komunikasi dalam bentuk membagi informasi dan pengalaman serta emosi, menyangkut. kemung-kinan tindakan terhadap pelaku kekerasan itu, dan (c) perilaku agresif partisipatif dalam bentuk bekerjasama melakukan persiapan untuk aksi pembalasan.

Kondisi politik dan ekonomi kita yang belum menunjukkan tanda-tanda membaik bahkan makin sulit ini. merupakan pemicu meluasnya gejala ketakutan pada kekerasan ini karena ia secara mudah bisa dikaitkan langsung oleh masyarakat 
terhadap .potensi kekerasan, di samping tentu saja krisis kepercayaan masyarakat kepada aparat.

Khusus terhadap alasan kedua' (krisis kepercayaan pada aparat) boleh jadi dilatarbelakangi oleh pengalaman selama ini, dimana aparat (polisi) kita secara umum tidak dipercaya, berkaitan dengan kinerja, mentalitas dan lain-lain. Situasi ini sebenarnya tidak sepenuhnya kesalahan polisi secara pribadi, tetapi dalam konsep kerja polisi yang dituntut bergerak dalam kerangka on the job trouble dan within the job trouble tidaklah semudah memba=yangkannya. Disatu sisi polisi dihadapkan pada masalah bagaimanaharus patuh padaperintah atasan yang menuntut kerja efektif, efisien dengan target-target dan prioritas-prioritas. Keberhasilan atau kegagalan mengemban perintah atasan berkaitan langsung dengan kondite dan karir.

Sementara di sisi lain dalam konteks within the job trouble yang menuntut kecakapan kerja, ketelitian dan sikap adaptif terhadap dan di dalam masyarakat membuat Polisi terkesan lamban, tidak efektif dan efisien dihadapan atasan, bahkan dalam pandangan masyarakat sendiri, karena tidak jarang untuk jenis kejahatan yang meresahkan, masyarakat justru menuntut Polisi secepat mungkin menangkap dan memenjarakan pelaku.

Tuntutan efektivitas dan efisiensi kerja di satu sisi dan keharusan bekerja dalam kerangka aturan, prosedur merupakan faktor situasional dalam internal polisi yang membuat kinerja polisi terkesan tak terkoordinasi dan terkontrol dengan baik. Kecenderungan polisi mengejar efektivitas, efisiensi, prioritas terselenggaranya stabilitas demi karir dengan mengabaikan hukum mem-buat citra Polisi sebagai pelanggar HAM. dan hukum menguat; sementara konsisten dengan hukum beresiko lamban dan berlarut. Dilema ini paling kurang telah membuat kinerja Polisi seperti. kehilangan orientasi dan energi sehingga berdampak pada melemahnya daya tangkal Polisi terhadap kekerasan. Dan ini acapkali diajukan sebagai argumen menjawab kritik menurunnya kinerja Polisi.

\section{Munculnya Respon Agresif}

Masalahnya bagaimana dan apa yang tejjadi apabila aparatresmi, karena berbagai faktor, menjadi kurang mampu untuk menanggulangi kekerasan; sementara kekerasan terus mengancam. Apakah masyarakat tetap akan tunduk dan patuh pada doktrin-doktrin hukum modern, seperti tidak main hakim sendiri, asas praduga tak bersalah, dan sebagainya? Apakah sistem kontrol sosial buatan akan mampu menundukkan sistem yang alami?

Dalam sejarah, kontrol terinadap kejahatan tidak dimulai dengan menciptakan sistem formal, seperti sistem peradilan pidana modem yang umum dipakai didunia. Sebaliknya, ia dimulai dari kontrol tradisional yang lebih bersifat alami. Kontrol yang demikian itu disebut sebagai vigilantism. Kontrol sepenuhnya berada di tangan masyarakat. Sistem kontrol yang demikian itu mendominasi masyarakat Amerika, yang pada masa petualangannya dua ratus tahun lalu dikenal sebagai the American frontier, yaitu pada waktu baru mulai menyusun kehidupan di benua baru Amerika.

Institusi polisi waktu itu belum ada dan masyarakat harus mengorganisasi sendiri kekuatannya untuk menghadapikejahatan dan ketidaktertiban (disorder). Kelompok siaga atau viqilantes itu disusun dengan cukup baik dan disiapkan untuk menghadapi kejahatan tertentu, misalnya untuk memerangi gelombang perampasan dan pencurian. Kelompok yang dipimpin oleh 
anggota masyarakat yang terhormat itu mencari mereka yang dicurigai sebagai pelaku kejahatan, menyelenggarakan pengadilan dan menerapkan pemidanaan terhadap mereka. Apabila tujuan untuk menangani kejahatan dan ketidaktertiban sudah tercapai, maka kelompok itu biasanya dibubarkan. Tetapi terkadang kelompok tersebut juga tetap berdiri dan dengan demikian sudah mirip dengan badan yang menjalankan fungsi kepolisian secara tetap. Kelompok siaga di Amerika memiliki karakteristik kerjanya sendiri, yaitu dengan cara melanggar hukum, main hakim sendiri, dan dengan mengambil alih penegakan hukum yang semestinya dilakukan oleh pemerintah.

Kendatipun kelompok siaga tersebut banyak memberikan sumbangan terhadap keamanan dan stabilitas masyarakat, tetapi kita sebaiknya juga mendengar pendapat lain yang mengatakan bahwa secara halus kultur kelompok siaga tersebut menggerogoti penghormatan kita terhadap hukum dengan sewaktu-waktu memberikan kebebasan untuk memilih; apakah kita akan tetap berpegangan pada hukum atau tidak. Di Indonesia, jejak-jejak kelompok siaga juga dapat ditemukan, seperti pada kelompok pemuda Bandung ahli karate dan pemuda Cabang Kuta di Bali. Mereka juga telah berperan sebagai kelompok siaga yang ingin membersihkan masyarakat.

Dalam kaitan itu, sekarang mulai terasa gelagat munculnya respon agresif kolektif masyarakat kepada pelaku kekerasan. Dalam beberapa kasus kejahatan misalnya, masyarakat tanpa rasa takut melakukan pengadilan beramai-ramai, bahkan pelaku yang ditahan polisi pun diminta untuk diserahkan kepada pengadilan massal itu, dengan mengancam akan menghancurkan kantor polisi jika pelaku tidak diserahkan.
Perundang-undangan kita boleh dikatakan setia kepada doktrin legalisme liberal yang tidak memberikan tempat sedikitpun kepada kekuatan masyarakat untuk melindungi dirinya. Oleh sebab itu dalam konteks konsep dan struktur HAM yang dominan serta tuntutan tegaknya negara hukum (rule of law), maka kehadiran kelompok masyarakat yang menjelma menjadi pengadilan jalanan ini merupakan suatu anomali.

Oleh sebab itulah, pikiran-pikiran jalan pintas dengan argumentasi yang kedengarannya masuk akal, harus ditakar dengan resiko atau kerugian-kerugian yang akan timbul.Reformasi mendasar Kepolisian kita sudah seharusnya melahirkan sikap, pandangan (perspektif), dan pola kerja baru yang lebih responship dengan jiwa negara demokrasi dan HAM. Sangat ganjil rasanya jika UU yang ada sudah menunjukkan semangat demokrasi sementara aparatur penegaknya masih pola lama; defensif, represif, dan militeristik.

\section{Penutup}

Fenomene sosial kekerasan tidak saja dapat dijelaskan dan terkait dengan dan di dalam aspek-aspek struktural, tetapi juga dengan gejala anomoli-anomali sosial, politik, hukum dan prilaku tokoh atau pemimpin. Pada masyarakat Barat barangkali tidak relevan mengajukan aspek terakhir ini sebagai salah satu kausa kekerasan, tetapi di masyarakat kita dimana relasi sosial tokoh atau pemimpin dengan rakyat atau umatnya dibingkai dengan kepercayaan sosial dan bahkan spiritual, maka relasi itu memiliki dimensi psikologis dan magnetik yang khas, yang bisa secara ekstrim menjadi faktor stabilisasi, tetapi juga faktor anarki; tergantung bagaimana citra pemimpin atau tokoh di kalangan pengikutnya. 
Begitu pula dengan prilaku berhukum mereka yang seharusnya menjadi pihak pertama menghormati, menghargai dan menegakkan hukum sebagaimana mestinya cita-cita bernegara hukum (supremasi hukum) amat menentukan sikap, pandangan dan prilaku hukum masyarakat. Perilaku inkonsistensi atau bahkan penghianatan terhadap hukum, sebagaimana dipertontonkan Mahkamah Agung (MA) beberapa waktu belakangan ini dapat memperluas apatisme, terutama krisis kepercayaan kepada hukum termasuk dan terutama kepada aparturnya. Kalau sudah demikian, ketidakhormatan dan ketidakpercayaan kepada hukum bisa lebih tinggi. Dan yang patut dikhawatirkan, krisis kepercayaan kepada hükum di era sekarang ini bisa berdampak luas dibanding era Orde Baru yang laiu, karena faktor kekuasaan yang dulu menjadi hukum dan bahkan di atas hukum yang selalu mampu meredam setiap gejolak sosial telah melemah; kehilangan dominasi dan hegemoninya, seiring dengan menguatnya masyarakat sipil.

Oleh sebab itu, fungsi dan peran hukum dan aparatur penegak hukum itu sendiri harus berada di depan dalam upaya mengendalikan kekerasan dan menekan seminimal mungkin ketakutan pada kekerasan dengan cara pertama-tama dan utama konsisten; tidak pandang bulu atau tebang pilih. Sikap dan tindakan hipokrisi dari dan oleh penegak hukum itu sendiri harus diakhir. Kalau tidak bangsa ini akan menjadi negara hukum demokrasi mitos, yang setiap hari membuktikan kebohongankebohongannya. Dan karena itu pula, hukum harus diyakini sebagai sesuatu yang secara terus menerus harus direbut dan diwujudkan kembali. Hukum beserta aparaturnya hanya bisa menjaga kelangsungan hidupnya yang kontinyu; dan hanya dengan keteguhan kemauan dan usaha demikianlah, satu kelompok atau individu akan mampu mengidentifikasi dirinya dengan hukum, mampu merenggut hukum bagi dirinya dan, dengan demikian, mampu mendudukkan dirinya sebagai subjek hukum.

Senada dengan itu, Von Jhering (Peters dan Koesrini:1990) juga menyatakan bahwa hukum tidak lahir dengan sendirinya, tetapi harus direbut. Anggapan bahwa hukum dapat muncul dengan sendirinya merupakan salah satu pelajaran yang paling menyesatkan dan fatal karena gagasan ini malahan membujuk orang yang seharusnya mengerahkan daya upaya dan tindakan, menjadi menunggu dan menaruh kepercayaan pasif pada hukum. Kegairahan suatu bangsa dalam berpegang dan menyandar pada hukumnya, sekaligus menentukan keteguhan upaya bangsa itu dalam mencurahkan jerih payahnya untuk menghasilkan hukum tersebut.

Jikalau sekelompok orang yang memperoleh haknya dari undang-undang, kemudian membiarkan pihak lain melanggar hak-haknya itu, dan menerima saja keadaan yang ia alami, maka bukan saja mereka akan dirugikan, tetapi kejadian itu dipastikan akan berulang terus, dan dengan demikian, undang-undang itu pun akan kehilangan segala wewenangnya, dan dengan membiarkan tindakan itu berarti mereka mengungkapkan sikap tidak merasa perlu memperlakukan insan hukum secara sungguh-sungguh.

Mengakhiri tulisan ini, menarik mengutip roman "hutan rimba" dari Albert Helman yang berjudul "De stille plantage" (perkebunan yang hampa): orang membuka hutan dan memulai perkebunan; untuk membina dan mempertahankarinya perlu upaya dan perjuangan yang tak kenal henti; apa yang disediakan dan didapat dari alam harus direbut setiap hari; satu hari istirahat berarti kehilangan sepetak tanah kebun; jika 
ditinggalkan beberapa tahun, maka yang dapat ditemukan setelah kembali hanyalah rimba-blukar yang telah menaklukkan perkebunan dan tak sedikit pun kebun tersisa (Peters dan Koesrini: 1990).

\section{Daftar Pustaka}

Camara, Dom Helder, (2000). Spiral of Violence Sheed and Ward. Terjemahan Komunitas Apiru: Spiral Kekerasan. Yogyakarta: INSIST Press dan Pustaka Pelajar.

Erich Fromm, (2001). The Anatomy of Human Destructiveness. Terjemahan Imam Muttaqin: Akar Kekerasan, Analisis Sosio-psikologis atas Watak Manusia. Yogyakarta: Pustaka Pelajar.

Fisher, Simon, dkk.; (2001). Working with Conflict: Skills and Strategies for Action. Terjemahan S.N. Kartikasari: Mengelola Konflik, Keterampilan dan Strategi untuk Bertindak. Jakarta: The British Council, Zed Books, dan Responding to Conflict.

Galtung, Johan, (1990). "Cultural Violence", dalam Journal of Peace-Research Volume 27 Number 3.

, (2002). "Kekerasan Kultural", dalam Jurnal Wacana, Edisi 9 Tahun III, Yogyakarta: INSIST Press.

Heffelbower, Duane Ruth, (2001). "Reconciling Injustices A Process for Indonesia." Islamic Millenium Journal Volume 1/Number 1/September-November 2001.
Karim, Abdul Gaffar, dkk., (2000). Melucuti Serdadu Sipil Mengembangkan Wacana Demiliterisme dalam Komunitasd Sipil. Yogyakarta: FISIPOLUGM.

Mohtar Mas'oed, dkk., (1997). Perilaku Kekerasan Kolektif: Kondisi dan Pemicu. Laporan Penelitian. Yogyakarta: Pusat Penelitian Pembangunan Pedesaan dan Kawasan UGM dan Departemen Agama R.I.

Mubarok, Ahmad, (2001). "Reconciliation: The Quranic Perspective." Islamic Millenium Joumal Volume I/Number 1/September-November:2001.

Peters dan Koesrini (ed) (1990), Hukum dan Perkembangan Sosial Buku Teks Sosiologi Hukum, Buku III, SH.

Quinney, Richard,(1978), Criminology, Little, Brown Company.

Rahardjo, Satjipto, dan Anton Tabah, (1993). 'Polisi Pelaku dan Pemikir, Jakarta: Gramedia Pustaka Utama.

Schulte-Nórdhoit, Henk, (2002). "Asal-usul Kekerasan", dalam Jurnal Wacana, Edisi 9 Tahun III, Yogyakarta: INSIST Press.

Santoso, Thomas, (2002) Teori-Teori Kekerasan, Ghalia Indonesia.

Salmi, Jamil, (2005), Violence and Democratic Society Hooliganisme dan Masyarakat Demokrasi, PILAR. 